\title{
Monitoring of terrestrial hydrology at high latitudes with scatterometer data
}

\author{
Annett Bartsch \\ Vienna University of Technology \\ Austria
}

\section{Introduction}

The mission of this chapter is to provide insight into the capabilities of scatterometer data for climate change relevant monitoring at high latitudes of the terrestrial hydrosphere (excluding large ice caps). Scatterometer are active microwave instruments. Spaceborne sensors have been developed for operational ocean wind monitoring but they have also been proven of high value for applications over land area within especially the last decade (Wagner et al., 2007). The applications cover a wide range of subjects from snowmelt to phenology. What all have in common is the focus on monitoring of dynamic processes.

Scatterometer are non-imaging radars. Currently operational sensors which are used for land applications operate in $\mathrm{Ku}-(\approx 2.1 \mathrm{~cm}$ wavelength) and $\mathrm{C}$-band $(\approx 5.6 \mathrm{~cm}$ wavelength $)$. The spatial resolution is coarse compared to most optical and SAR sensors and ranges between $25 \mathrm{~km}$ and $50 \mathrm{~km}$. The temporal resolution, however, can be better than daily especially at high latitudes as they are mounted on polar orbiting platforms what results in overlapping orbits. Especially issues in hydrology require a high sampling rate. The interaction of the electromagnetic waves at the earth surface is influenced by dielectric properties, roughness and land cover parameters such as vegetation (Ulaby et al., 1982). Additionally the properties of the waves (frequency, polarization, incidence angle) determine the sensitivity to certain changes (spatially and temporally) at the earth surface. For the derivation of most land surface parameters single sensor approaches have been developed which exploit the specific sensor properties. As the backscatter return is complex to model, they are largely based on change detection approaches. These parameters and thus results from scatterometers with different configurations can be jointly used in order to get an advanced insight to earth surface processes and long term changes (Bartsch et al., 2007a).

The focus of this chapter is on applicability of scatterometer products for investigation of basin hydrology. High latitudes are of special interest for climate change monitoring (Hinzman et al., 2005; IPCC, 2007). Predicted and observed changes affect the hydrosphere, especially snowmelt timing (Dye \& Tucker, 2003; Smith et al., 2004) and permafrost (e.g. Callaghan et al. (2004)). Scatterometers provide valuable data for the monitoring of these changes on regional to global scale. River runoff maxima occur in conjunction with snowmelt (e.g.Khan et al. (2008); Yang et al. (2007)). These melt patterns can be determined using scatterometer products (Bartsch et al., 2007b; Frolking et al., 1999; Kimball et al., 2004a; 
Wismann, 2000). Frozen ground impedes drainage (French, 1996; Lilly et al., 2008; Williams \& Smith, 1989) and may thus impact the relationship between snowmelt patterns and river discharge (Kane, 1997; Kane et al., 2003). When snowmelt has ceased changes in discharge result from e.g. precipitation and subsurface melt. Near surface soil water content can be also captured with active microwave data and therefore allow an assessment of the hydrological status of entire basins (Scipal et al., 2005).

In the following sections, available sensors and change detection approaches relevant to basin hydrology at high latitudes are reviewed and eventually results for selected basins presented and discussed.

\section{Sensors and data}

ERS-1 has been launched in 1991 and ERS-2 in 1996. The wind scatterometer on these platforms provide $50 \mathrm{~km}$ resolution datasets in C-band. A global coverage can be theoretically achieved within 3-4 days (Wagner et al., 1999a). A similar sensor has been launched with METOP ASCAT (Advanced Scatterometer) in October 2006. The ground coverage is considerably improved compared to ERS due to a second swath and spatial resolution is $25 \mathrm{~km}$ (Klaes et al., 2007). Measurements are consistent with the preceding sensors and allow continuation of products developed for ERS (Bartalis et al., 2007; Naeimi et al., 2009).

First Ku-band scatterometer studies are based on NSCAT onboard the Advanced Earth Observation Satellite (ADEOS). It was launched on August 1996 and operated until June 1997. The spatial resolution was $25 \mathrm{~km}$ and a $90 \%$ global coverage has been achieved within two days allowing for twice daily acquisitions at high latitudes (Frolking et al., 1999). The later Seawinds instruments (on QuikScat and ADEOS2) cover $90 \%$ of the Earth's surface daily and provide up to 10 measurements towards $75^{\circ} \mathrm{N}$ (Bartsch et al., 2007b). Seawinds QuikScat is also a $\mathrm{Ku}$-Band sensor with $25 \mathrm{~km}$ resolution and is to date in operation.

Important steps in the preprocessing of scatterometer data are normalization and gridding as they are non-imaging radars. Normalization is required since the incidence angle varies from acquisition to acquisition what causes differences in backscatter. Both NSCAT and ERS measurements are usually normalized to $40^{\circ}$ (Kimball et al., 2001; Wagner et al., 1999a; Wismann, 2000; Zhribi et al., 2008). Nghiem \& Tsai (2001) used $45^{\circ}$ for NSCAT. Often scatterometer data have been gridded into rectangular cells of e.g. $0.5^{\circ} \times 1^{\circ}$ (Prigent et al., 2007; Wismann, 2000), $0.5^{\circ}$ x $0.5^{\circ}$ (Abdel-Messeh \& Quegan, 2000) or $0.25^{\circ} \times 0.25^{\circ}$ (Zhribi et al., 2008) for ERS, $25 \mathrm{~km}$ x $25 \mathrm{~km}$ for NSCAT (Kimball et al., 2004a; 2001; Nghiem \& Tsai, 2001) and $12.5 \mathrm{~km} \times 12.5 \mathrm{~km}$ for QuikScat (Kidd et al., 2003). The TU Wien ERS product (Scipal, 2002) uses a Discrete Global Grid (DGG) which is a sinusoidal global grid generated by an adapted partitioning of the globe with orininally a $25 \mathrm{~km}$ grid spacing for ERS and recently a $12.5 \mathrm{~km}$ grid incorporating also ASCAT (Bartalis et al., 2006; Naeimi et al., in press). The spatial interpolation of the data in each grid point is performed after the incidence angle normalization of the backscatter measurements in $\mathrm{dB}\left(\sigma^{0}\right)$, by using the Hamming window function (Scipal, 2002). A resolution enhanced QuikScat product has been developed based on multiple measurements available during short time intervals (Early \& Long, 2001). QuikScat $\sigma^{0}$ data are made available as "eggs" or "slices" depending on the processing method. Egg-based QuikScat images have a nominal pixel spacing of $4.45 \mathrm{~km}$ and an estimated effective resolution of 8-10 km (Long \& Hicks, 2005, BYU product). Daily "eggs" 
data have been used by Hardin \& Jackson (2003), Frolking et al. (2005), Brown et al. (2007) and Wang et al. (2008) for land applications outside glaciated areas. On a global level those are assembled from four days of data and for polar regions for separated day times due to increased revisit intervals (applied in e.g. Wang et al. (2008)).

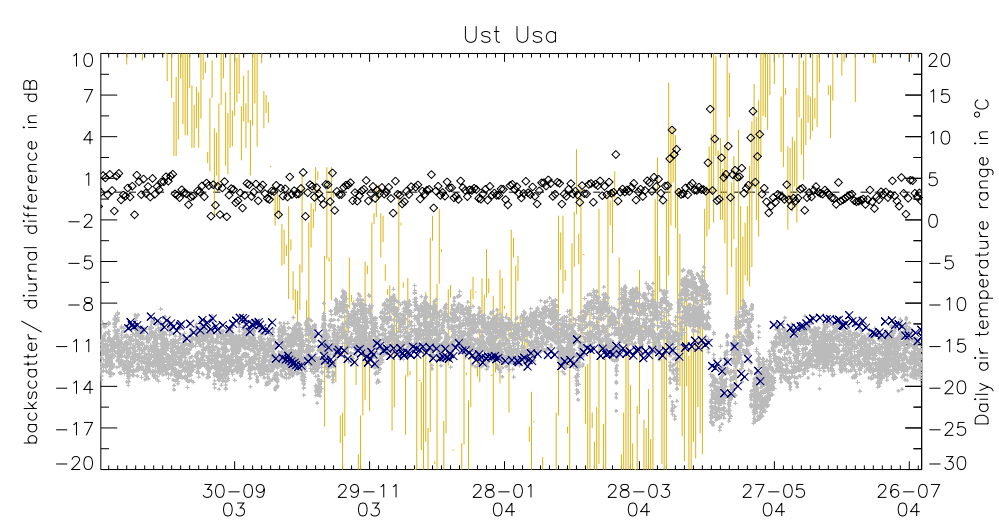

Fig. 1. Typical backscatter time series (in dB) for C-Band (blue crosses, source: ERS) and Kuband (grey points, source: QuikScat) at Ust Usa $\left(56.92^{\circ} \mathrm{E}, 65.97^{\circ} \mathrm{N}\right)$ for August 2003 to July 2004. Daily air temperature range in ${ }^{\circ} \mathrm{C}$ extracted from the WMO512 dataset is shown as yellow bars. Diamonds represent Ku-band diurnal backscatter difference in $\mathrm{dB}$.

A typical backscatter time series of C-band (ERS) and Ku-band (QuikScat) for high latitude environment is shown in Figure 1. Although there are similarities in surface interaction, seasonal backscatter behaviour differs between $\mathrm{Ku}$ - and $\mathrm{C}$-Band. This is especially pronounced if a snow cover is present. Microwave backscatter differs significiantly due to changing dielectric properties between frozen and unfrozen ground (e.g. Ulaby et al. (1982); Way et al. (1997); Wegmüller (1990)). In case of Ku-band, the backscatter is low before snow arrival, it gradually increases with snow accumulation, then rapidly decreases when the snow starts melting and eventually increases again when all snow has melted (Nghiem \& Tsai, 2001). The level of summer backscatter is lower than winter backscatter. In C-band, the summer backscatter is higher than when snow is present or the ground is frozen. When the snow surfaces recyristallize after a midwinter short-term melt event, backscatter can increase up to summer levels in C-band (Wismann, 2000). The formation of ice crust after mid-winter thaw and subsequent backscatter increase is also strongly visibly in Ku-band (Kimball et al., 2001). QuikScat also allows the investigation of diurnal differences during the snowmelt period (Bartsch et al., 2007b; Nghiem \& Tsai, 2001). The snow is then often frozen in the morning and the surface is undergoing melt in the evening due to air temperatures increase above $0{ }^{\circ} \mathrm{C}$ during the day. This results in strong differences between morning and evening backscatter (Figure 1).

Microwave backscatter during freeze/snow free conditions increases with increasing soil moisture (Ulaby et al., 1982). This has been demonstrated for C-band (e.g. Wagner et al. (1999b); Zhribi et al. (2008)) and Ku-Band (Mladenova et al., in press) scatterometer. 
Additionally, variation in summer can be caused by phenology. Backscatter increases with vegetation growth (Frolking et al., 2005; Hardin \& Jackson, 2003). The magnitude of contribution at C-band is, however, low compared to soil water changes (Wagner et al., 1999c).

Tundra regions are often characterized by a high number of small lakes and ponds which can be easily identified with higher resolution microwave satellite data (Synthetic aperture radars - SARs) due to the specific low backscatter of smooth water surfaces (e.g. Bartsch et al. (2008a). For coarse resolution data such as from the ERS scatterometer, however, it has been found that contributions of lakes and rivers to the overall backscatter is very small and can be neglected (Wismann, 2000).

Variations in backscatter are also introduced by instrument noise, speckle and azimuthal effects (Wagner et al., 1999b). In C-band especially azimuthal effects add to noise for different land cover types (Bartalis et al., 2006; Naeimi et al., in press). Seawinds QuikScat data exhibit also strong noise which varies over differing land cover (Bartsch et al., 2007b). Figure 2 demonstrates the typical noise at Ku-Band of un-glaciated terrain in high latitudes (Estimated standard deviation of noise - ESD). It is much higher than the ESD determined for ASCAT in those environments (Naeimi et al., in press). It is typically below $0.3 \mathrm{~dB}$ for ASCAT. It usually exceeds $0.5 \mathrm{~dB}$ (mean of 0.57 above $60^{\circ}$ north) for QuikScat. This needs to be accounted for especially when change detection methods which use thresholds are applied.

C-band scatterometer (ERS-1, Metop ASCAT) find mostly application for detection of soil moisture changes (Bartalis et al., 2007; Wagner et al., 1999b; Zhribi et al., 2008). The higher sensitivity to changes in snow properties of the shorter Ku-band (from Seawinds/QuikScat and NSCAT) is employed for mostly glaciological and seasonal snow cover monitoring applications. These sensors have been also investigated outside the high latitudes for phenology (Frolking et al., 2005; Hardin \& Jackson, 2003; Oza \& Parihar, 2007; Prigent et al., 2001), urban mapping (Nghiem et al., in press) and soil moisture (Mladenova et al., in press) applications.

\section{Change Detection Approaches}

\subsection{Freeze/thaw and snow monitoring}

First analyses of scatterometer for seasonal thaw are based on ERS-1 data as complete coverage of seasonal cycles from this sensor are already available since 1992. Boehnke \& Wismann (1996) calculated the typical summer (July) and Winter (February) backscatter level in order to determine the thaw timing. When a minimum of $50 \%$ of the winter summer difference is exceeded for at least two consecutive measurements ground thaw is detected. However, since re-crystallization of snow can cause similar backscatter levels as during summer in C-band an enhanced method has been developed (Wismann, 2000) which applies additionally a maximum likelihood classification over neighbouring pixels in cases when the initial detection fails.

Although the available record of NSCAT (Ku-band) is rather short (eleven months) it provided a first dataset covering an entire northern hemisphere winter and spring period at this wavelength. Its suitability for detection of freeze/thaw was tested by Frolking et al. (1999). They introduced a change detection algorithm which considers differences between 


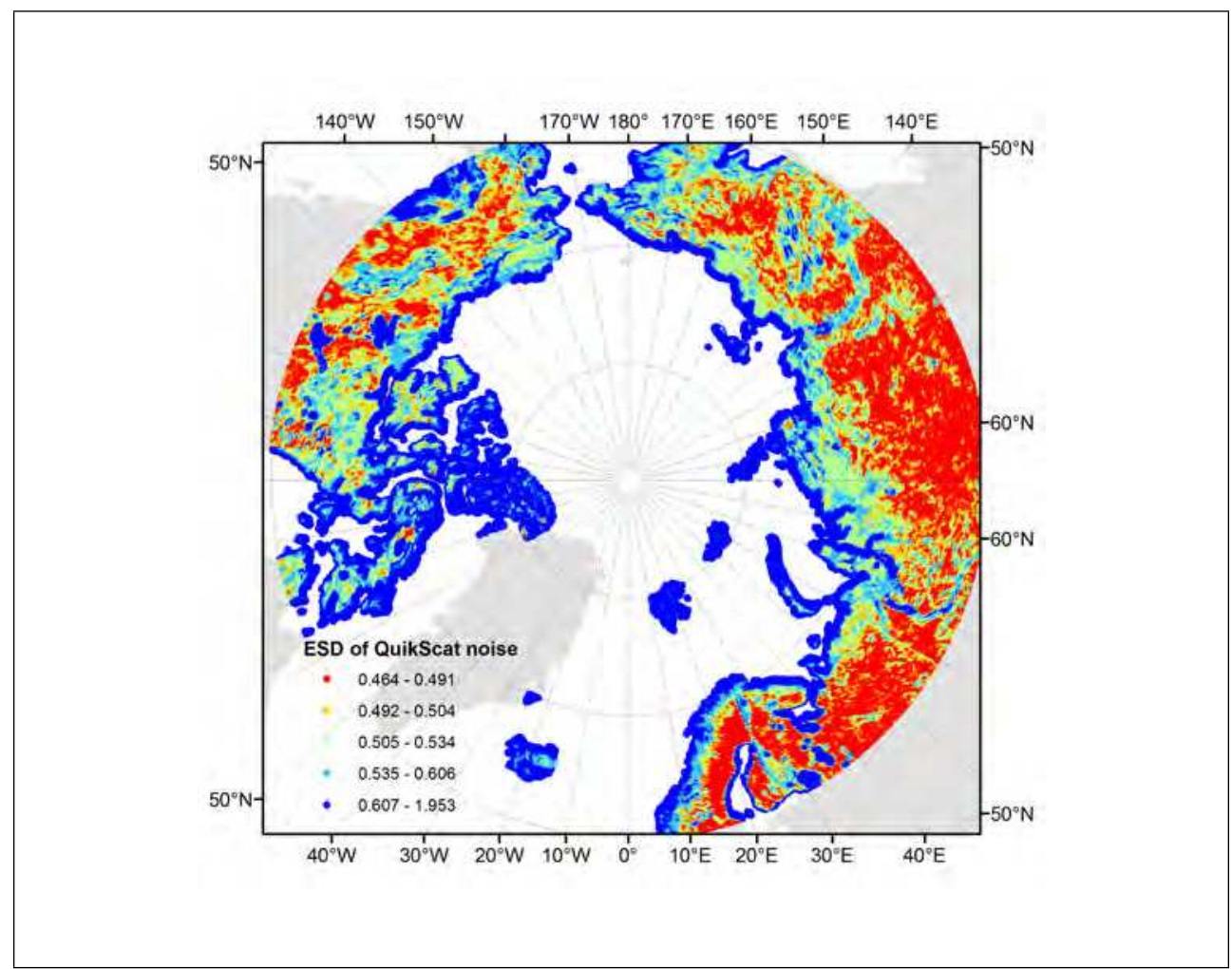

Fig. 2. Estimated Standard Deviation (ESD) of QuikScat long-term noise above $60^{\circ} \mathrm{N}$; oceans and ice caps are excluded

five day averages and location specific differences from the overall mean value. This approach has been build on and extended within a number of follow-up studies with Ku-Band scatterometer. Kimball et al. (2001) transferred the C-band approach of Boehnke \& Wismann (1996) to NSCAT data. The five day average method (Frolking et al., 1999) has been extended for NSCAT by extraction of three instead of one specific date of thaw: the start, the end and the primary thaw date which is the day with the highest backscatter difference (Kimball et al., 2004a). The five day moving average approach has been subsequently transferred to QuikScat (launched 1999) for final thaw date extraction and also applied in a similar way to autumn refreeze (Kimball et al., 2004b). A further method which is taking winter (February) mean backscatter into consideration is applying fixed thresholds for daily mean values in order to determine the onset of snowmelt (Brown et al., 2007). As QuikScat provides sufficient morning and evening measurement, a new adaptive approach based on diurnal thaw and refreeze of snow cover could be developed (Bartsch et al., 2007b; Kidd et al., 2003, TU Wien method). Thresholds are defined for each single grid cell depended on the estimated standard deviation of long-term noise (Figure 2) and the actual number of measurements available during each 12 hour period. Significant diurnal backscatter changes occur throughout the snowmelt period several times but not necessarily on subsequent days. This occurrence of 
multiple events has been solved with a clustering method. In case of multiple melt periods (several clusters of at minimum two days with diurnal thaw and refreeze), the last one is identified as the major melt period. An analyses limited to evening measurements using the five day average approach (Frolking et al., 1999) plus the summer mean backscatter (August) has been carried out by Wang et al. (2008). The evening values are taken from the BYU "egg" product (Long \& Hicks, 2005). Static thresholds are used for thaw day definitions and it is assumed that relevant melt periods are longer than two days. If multiple events occur, the longest has been selected. This does not account for short term interruptions and thus supplies the end of melt only with respect to the entire spring melt.

Advanced products are snow covered area and melt area. The snow covered area can be determined with all above mentioned approaches as well as with optical data (Scherer et al., 2005). The melt area can be derived with the methods of Kimball et al. (2001) or Bartsch et al. (2007b) as they consider beginning and end of spring thaw. This differs from glaciological applications where single days or consequtive days with surface melt need to be identified for melt season length determination (e.g. Tedesco (2007)) as any interruption of melt impacts the mass balance. Surface melt of seasonal snow cover, especially in relation to rain-on-snow events, affects thermal properties of the snow pack and the soil beneath (Putkonen \& Roe, 2003). Even, single days of thaw during spring can cause an increase in heterotrophic soil respiration (Bartsch et al., 2007b). The primary thaw day (Kimball et al., 2001) extracted for the year 2000 in the circum-boreal and -arctic regions showed good correlations $(R=0.75)$ with modelled timing of water content increase in the snowpack (Rawlins et al., 2005).

Current approaches are not applicable in regions where no continuous snow cover/frozen ground conditions during the winter time exists as they are designed to identify one seasonal thaw event or period only. The presence of snow itself is not considered in all approaches. The presence of melting snow causes decreased backscatter similar to water in both C-band and $\mathrm{Ku}$-Band. Independent whether ground thaw or snow thaw is sought for multiple thaw periods within one winter season need to be accounted for at all latitudes. This has been so far considered in two mapping approaches only (Bartsch et al., 2007b; Wang et al., 2008). The for QuikScat typical variations in noise are only accounted for by the TU Wien method (Bartsch et al., 2007b; Kidd et al., 2003).

\subsection{Soil moisture monitoring}

The only change detection method for the determination of surface soil moisture from scatterometer data has been introduced by Wagner et al. (1999a). It is based on the assumption that most backscatter variation within the freeze free period is caused by changes in soil water content. The minimum (dry reference) and maximum (wet reference) values are site specific. Once they have been determined from a sufficiently long enough record each measurement can be scaled between those boundary values and a relative near surface soil moisture content determined. These datasets are available globally (since 2002, Scipal (2002)) and in case of ASCAT in near-real-time (Naeimi et al., in press). They can be thus applied e.g. for operational applications such as assimilation into weather forecasts (Scipal et al., 2008). 


\section{Examples}

\subsection{Snow melt}

The TU Wien product which is based on an adaptive diurnal difference approach introduced by Bartsch et al. (2007b) can be applied to QuikScat data for the extraction of the beginning and the end of thaw. It has therefore been chosen for investigation of the melt area and river discharge behaviour over selected Russian basins. It considers the varying noise levels and captures the final thaw period with respect to multiple thaw events before the final snowmelt period and short term variations during spring thaw. Typical duration of final spring melt in central Siberia above $60^{\circ} \mathrm{N}$ is two weeks to one month.

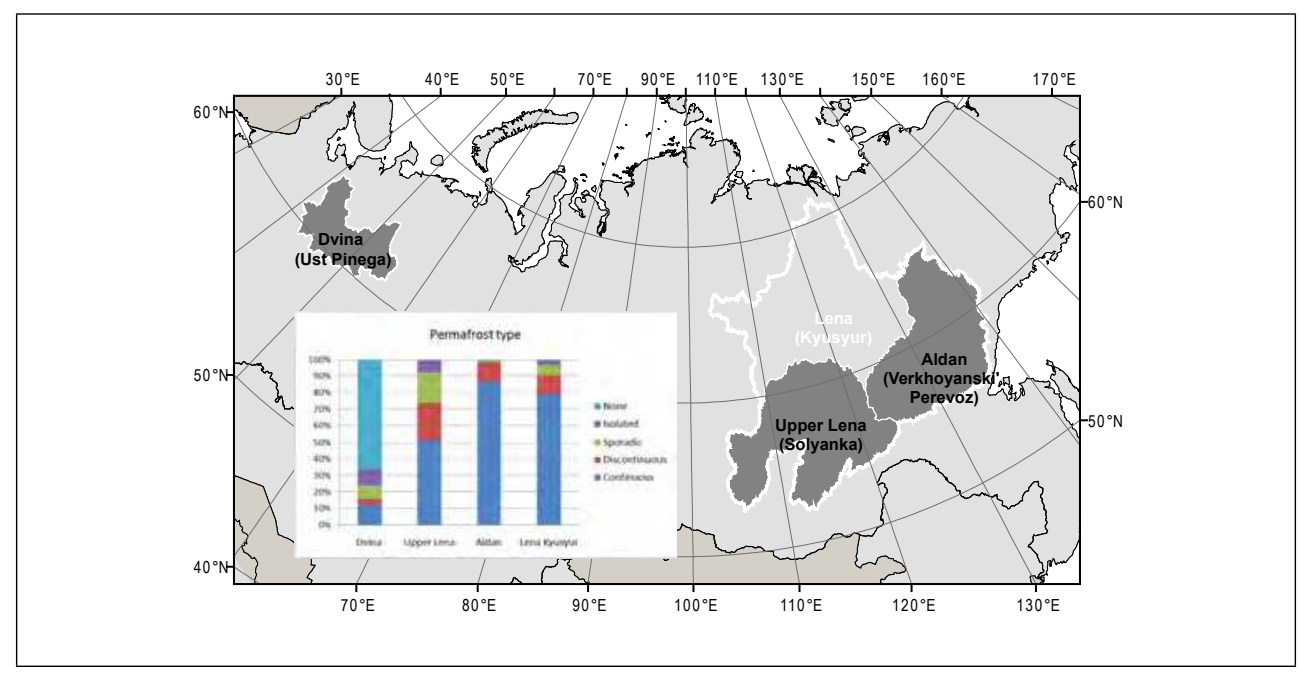

Fig. 3. Overview map of selected basins in Russia and proportion of permafrost types (source: NSDIC, Brown et al. (1998))

The area which undergoes snowmelt at a certain day has been extracted for three basins in Russia for the years 2001 to 2008 . Those are the Dvina upstream of Ust Pinega $\left(\approx 270.000 \mathrm{~km}^{2}\right)$, the Lena river upstream of Kyusyur $\left(\approx 2.440 .000 \mathrm{~km}^{2}\right)$ and two of its subbasins: the upper Lena upstream of Solyanka $\left(\approx 770.000 \mathrm{~km}^{2}\right)$ and the Lena river tributary Aldan (Verkhoyanski' Perevoz, $\approx 695.000 \mathrm{~km}^{2}$ ). These basins show varying Permafrost characteristics (Figure 3, source: NSDIC, Brown et al. (1998)). Dvina has only $12.5 \%$ continuous permafrost. This proportion is higher for all other selected basins, 50\% for upper Lena and $80 \%$ for Aldan and the entire Lena basin. The upper Lena basin constitutes most of the none-continuous permafrost of the Lena basin. Most of it, however, is also characterized by discontinuous and sporadic permafrost.

Figure 4 and Figure 5 show time series of melt area and discharge for the years 2001-2008. River runoff measurements are provided through ArcticRIMS (Regional, integrated Hydrological Monitoring System)/ R-ArcticNET (www.russia-arcticnet.sr.unh.edu). All basins are characterized by a pronounced runoff peak in spring. 

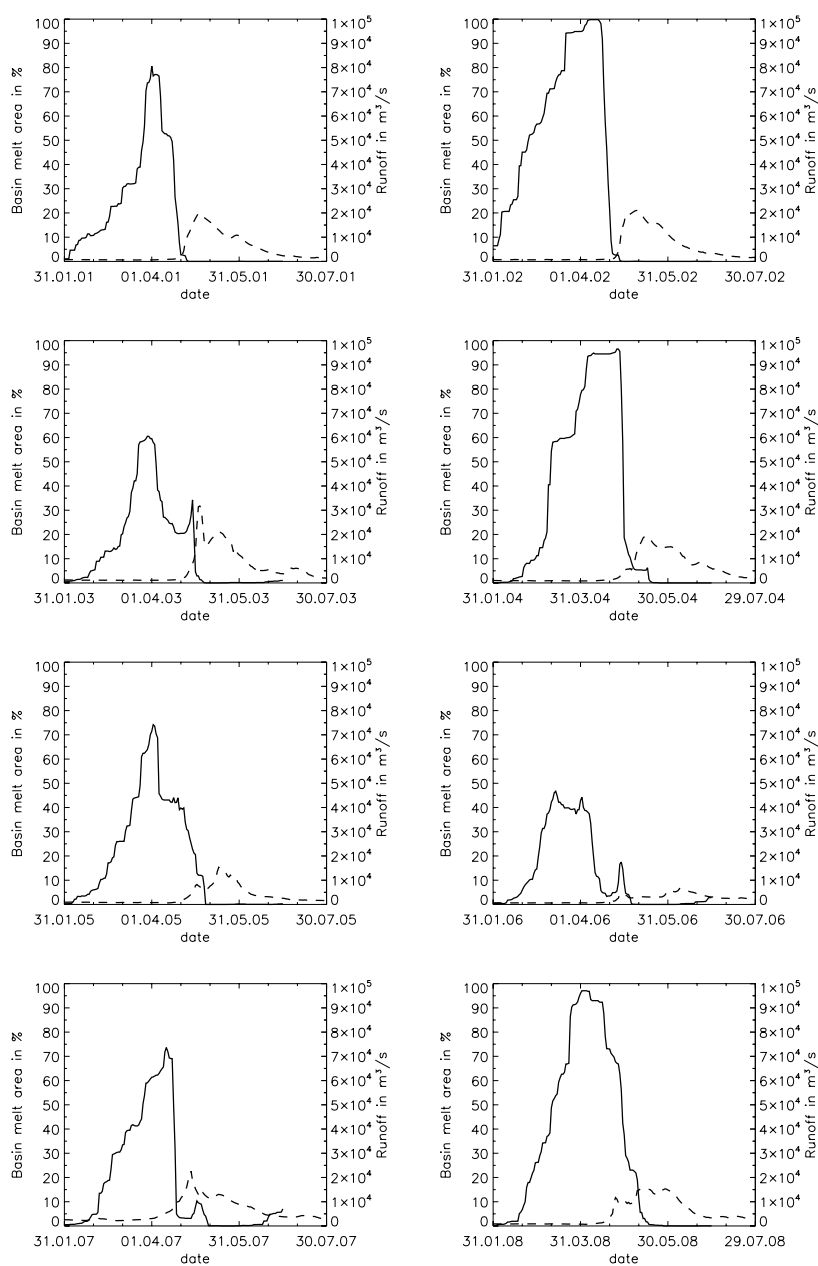

Fig. 4. QuikScat derived daily basin melt area in \% of the Dvina basin (solid line) and river discharge in $\mathrm{m}^{3} / \mathrm{s}$ at Ust Pinega (dashed line), 2001-2008

Dvina melt area and discharge measurements vary considerably over the eight analysed years. This applies to the magnitude as well as timing. The timing for the Lena is more constant and also does not vary much between the subbasins. Although the start of the snowmelt in the upper Lena basin is often earlier, it only slightly deviates from Aldan or entire Lena. This overlap may contribute to the distinct peak discharge observed at Kyusyur. The duration of spring snow smelt of Dvina is longer than for all Lena subbasins. This could be related to the higher average snow depth in the Eurasian Arctic than over the Lena basin (Khan et al., 2008). 

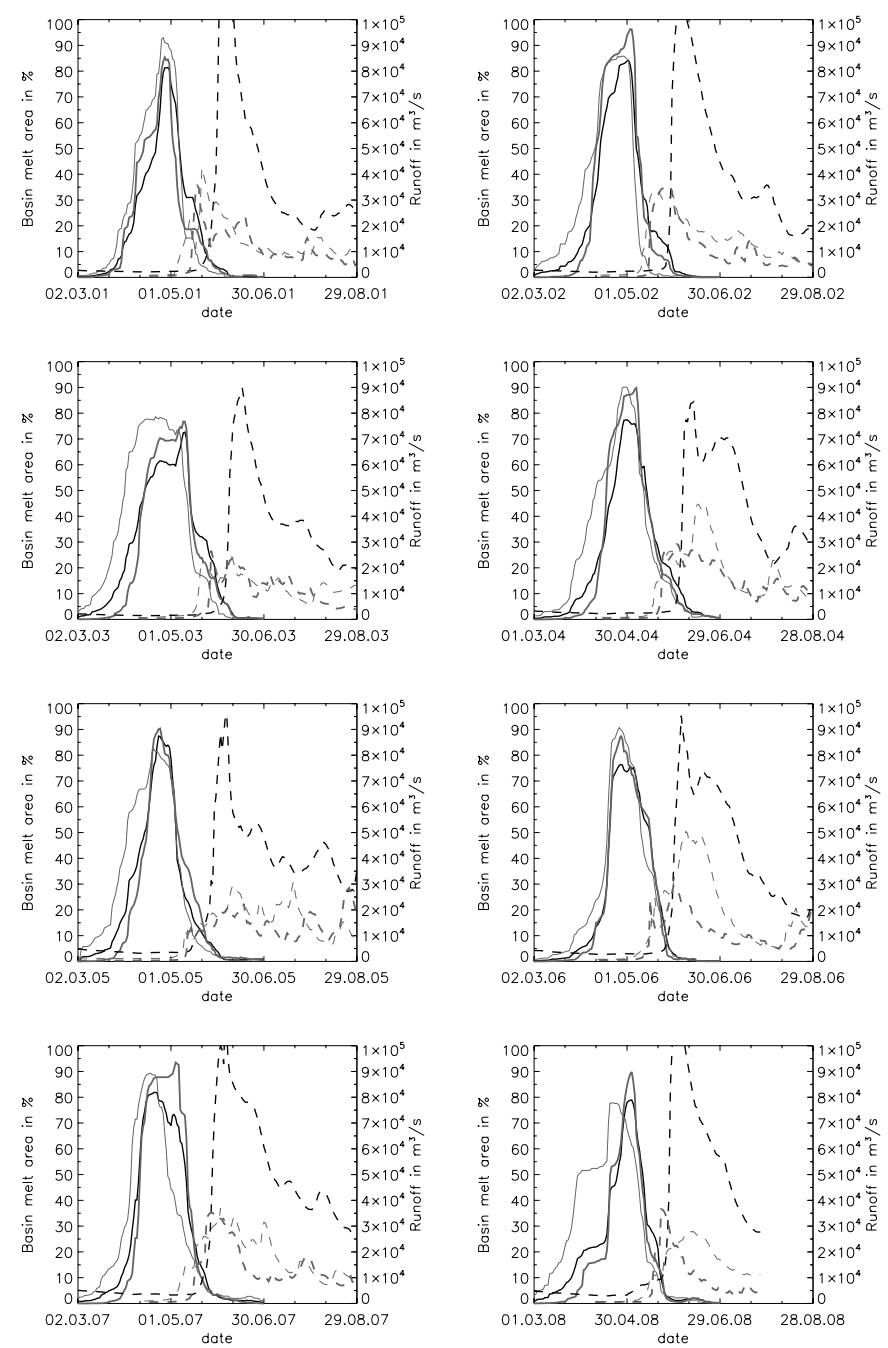

Fig. 5. QuikScat derived daily basin melt area in \% of the Lena Kyusyur basin (black solid thick line), Uppler Lena Solyanka basin (solid thin grey line), Aldan basin (thick grey solid line) and river discharge in $\mathrm{m}^{3} / \mathrm{s}$ at corresponding stations (dashed lines), 2001-2008

The magnitude of the melt area maximum and the river discharge spring maximum shows only a high correlation $\left(\mathrm{R}^{2}=0.79\right)$ for the upper Lena basin (Figure 6). This relationship is also partly visible for Aldan, but no distinct discharge peak could be observed in 2005 (Figure 5). The overall Lena basin spans over several degrees latitude and includes mountain ranges and therefore does not show a direct relationship. 

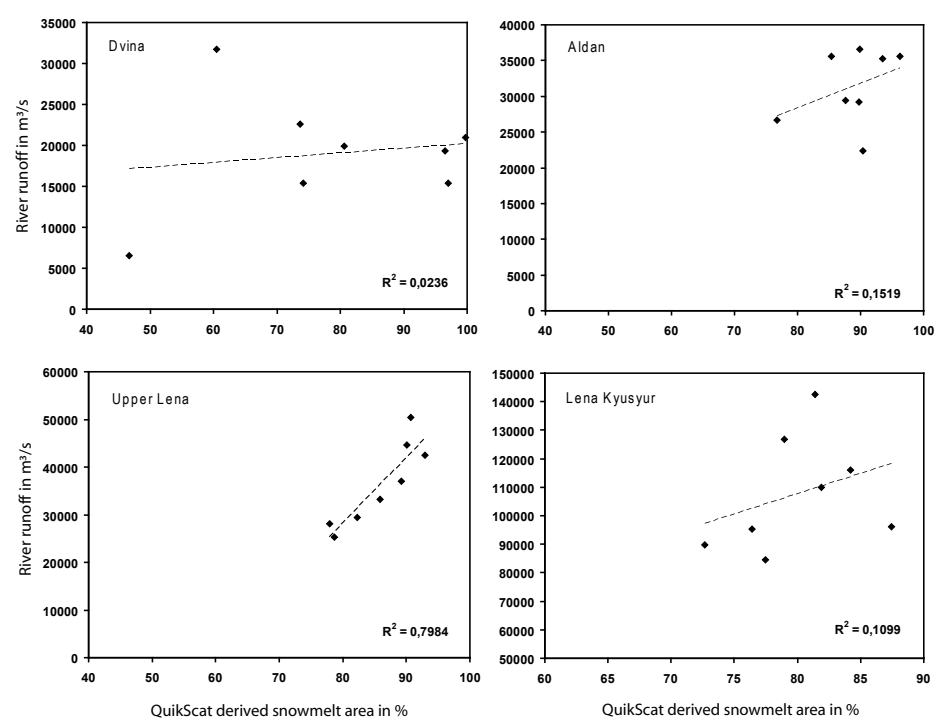

Fig. 6. Spring peak discharge $\left(\mathrm{m}^{3} / \mathrm{s}\right)$ and QuikScat derived annual peak basin melt area (in $\left.\%\right)$ comparison, 2001-2008

In order to compare the actual temporal offset between the melt area and discharge maxima for the different basins, the basin size needs to be taken into consideration. Therefore, the offset (in days) has been divided by basin area $\left(100.000 \mathrm{~km}^{2}\right)$. The normalized offset is shortest for Aldan and Lena (Kyusyur), somewhat longer in most years for the upper Lena and clearly longer (and more variable) for the Dvina basin (Figure 7). The higher the extent of continuous permafrost the shorter the temporal offset between melt area maximum and spring discharge peak.

\subsection{Near surface soil moisture}

River discharge measurements from subtropic environment have already shown to have high correlation with ERS estimated soil water index (SWI, Scipal et al. (2005)). The soil water index is derived from the original surface soil moisture product using an exponential function in order to model infiltration (Wagner et al., 1999a). The advantage is that moisture estimates for larger depths become available. The original measurements only represent the upper $2-5 \mathrm{~cm}$. The surface values are available in irregular intervals. The model output on the other hand supplies a regular 10-day dataset with respect to the varying global coverage. The percolation depth is static for the specified analyses region. However, if permafrost is present, the depth of unthawed ground (active layer) varies throughout the season. Therefore, 10-day means have been extracted from the original surface soil moisture calculations for the high latitude analyses. These values are averaged over the entire basins. In case of the Lena basin upstream of Kyusyur (Figure 3) a Pearson correlation of $\mathrm{R}^{2}=0.62$ between the basin mean 


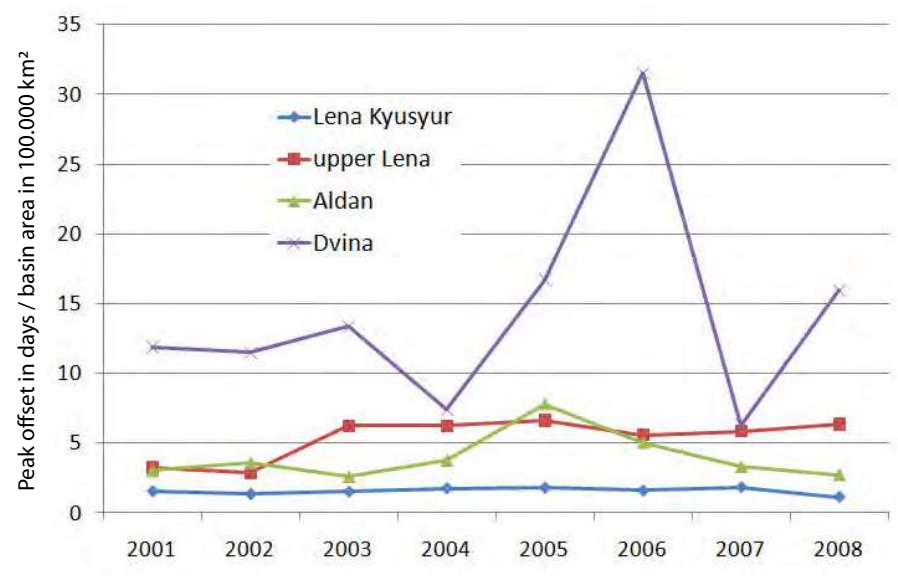

Fig. 7. Peak offset between spring discharge and QuikScat derived annual maximum melt area in days by basin area (in $100.000 \mathrm{~km}^{2}$ ), 2001-2008

surface soil moisture and the river discharge measured at Kyusyur can be determined for the summer periods (Mid-June to end of August) of 1992-2000 (Figure 8).

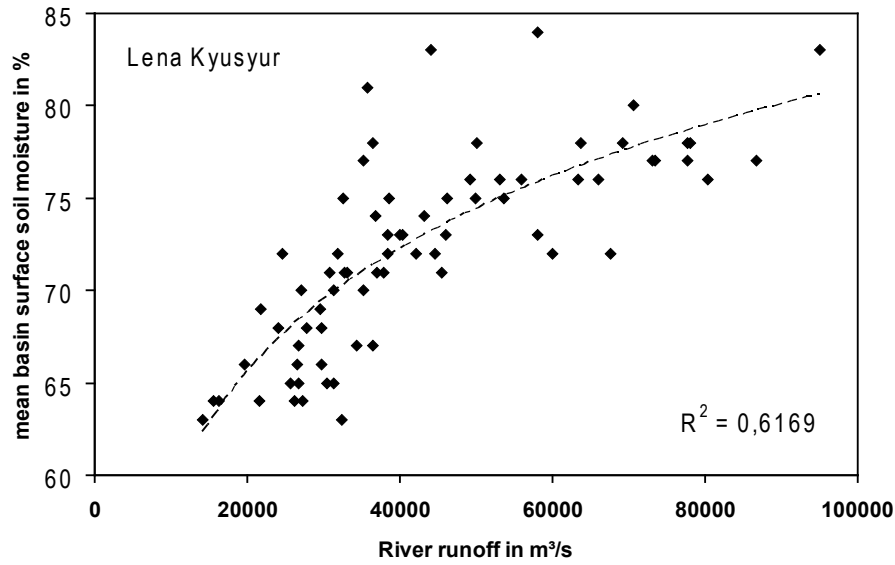

Fig. 8. ERS scatterometer derived 10-day mean basin surface soil moisture in \% and River discharge in $\mathrm{m}^{3}$ / $\mathrm{s}$ for the Lena Kyusyur basin, Mid-June to end of August 1992-2000 


\section{Discussion}

Variation in melt area and soil moisture can be introduced by variations in terrain and latitude. This has been show especially for the Mackenzie previously (Bartsch et al., 2007a). The use of the surface wetness in order to monitor runoff is only applicable when there are no other sources than rain or local ground thaw. This limits the application to regions without significant contribution by glacier melt water. Intermediate storage in lakes and wetlands can also decrease this relationship (Bartsch et al., 2007a). Surface wetness can be also derived from ScanSAR data as the ENVISAT ASAR operating in Global Monitoring Mode (Pathe et al., 2009). This provides more detailed $(1 \mathrm{~km})$ although less frequent measurements and has been also demonstrated to be correlated to river runoff in subtropical environments (Bartsch et al., 2008b).

Although drainage can be also impeded by other ground characteristics, a decrease in permafrost extent may impact the for those basins currently determined relationship between river discharge and both soil moisture and snow melt patterns. Additionally a change in greening-up dates has been observed during the recent decades (Myneni et al., 1997). A possible related change in snowmelt timing can be monitored with the currently available scatterometers complementary to optical satellite data which are impacted by cloud coverage. Continuation of C-band scatterometer is ensured until 2020 within the Metop series of satellites (Naeimi et al., in press). Both C-band and Ku-band scatterometer are widely used for ocean applications and therefore a need for continuation exists for different purposes. So far, the joint use of both bands was limited due to the unavailability of ERS data after 2000 for many parts of the globe. A synergistic use became now possible due to the launch of ASCAT. This will allow a comprehensive monitoring of catchment hydrology in regions with seasonal snow cover.

\section{Conclusion}

Scatterometer are capable of providing a range of climate change relevant land surface parameters. They are especially sensitive to changes in the hydrological cycle. Products cover freeze/thaw status, snowmelt patterns and soil moisture variations. C-band data have been especially proven valuable for soil moisture monitoring. The variation of surface wetness over Lena River basin with more than $\approx 80 \%$ continuous permafrost captured during the snow / freeze free period highly correlates to measured river runoff without any offset. This significantly differs from basins in subtropic environments with similar size where water can percolate deeper into the ground. This delays the transport to the river courses and offsets can be several months. An impact of impeded drainage over permafrost can be also observed for the peak runoff associated with spring snowmelt. The temporal offset between melt area maximum and river discharge maximum decreases with increasing proportion of continuous permafrost in the basin. The maximum melt area reached over basins with high proportion of continuous permafrost can correlate in cases with the magnitude of peak discharge $\left(R^{2}=0.8\right.$ for upper Lena). In spite of the coarse resolution of scatterometer data, they provide valuable operational monitoring tools of terrestrial hydrology at high latitudes on regional to circumpolar scale. 


\section{Acknowledgments}

This study has been funded by the Austrian Science Fund through the Hertha Firnberg program.

\section{References}

Abdel-Messeh, M. \& Quegan, S. (2000). Variability in ERS scatterometer measurements over land, IEEE Transactions on Geoscience and Remote Sensing 38(4): 1767-1776.

Bartalis, Z., Scipal, K. \& Wagner, W. (2006). Azimuthal anisotropy of scatterometer measurements over land, IEEE Transactions on Geoscience and Remote Sensing 44(8): 2083-2092.

Bartalis, Z., Wagner, W., Naeimi, V., Hasenauer, S., Scipal, K., Bonekamp, H., Figa, J. \& Anderson, C. (2007). Initial soil moisture retrievals from the METOP-a advanced scatterometer (ASCAT), Geophysical Research Letters 34: L20401.

Bartsch, A., Doubkova, M., Pathe, C., Sabel, D., Wolski, P. \& Wagner, W. (2008b). River flow \& wetland monitoring with ENVISAT ASAR global mode in the Okavango basin and delta, Proceedings of the Second IASTED Africa Conference, September 8-10, 2008 Gaborone, Botswana, Water Resource Management (AfricaWRM 2008), IASTED, pp. 152156.

Bartsch, A., Kidd, R. A., Wagner, W. \& Bartalis, Z. (2007b). Temporal and spatial variability of the beginning and end of daily spring freeze/thaw cycles derived from scatterometer data, Remote Sensing of Environment 106: 360-374.

Bartsch, A., Pathe, C., Wagner, W. \& Scipal, K. (2008a). Detection of permanent open water surfaces in central Siberia with ENVISAT ASAR wide swath data with special emphasis on the estimation of methane fluxes from tundra wetlands, Hydrology Research 39(2): 89-100.

Bartsch, A., Wagner, W., Rupp, K. \& Kidd, R. (2007a). Application of C and Ku-band scatterometer dara for catchment hydrology in northern latitudes, Proceedings of the 2007 IEEE International Geoscience and Remote Sensing Symposium. 23-27 July, Barcelona, Spain., IEEE.

Boehnke, K. \& Wismann, V. R. (1996). ERS scatterometer land applications: Detecting the thawing of soils in Siberia, Earth Observation Quarterly 52, ESA Publication Division.

Brown, J., Ferrians Jr., O. J., Heginbottom, J. A. \& Melnikov, E. S. (1998). Circum-arctic map of permafrost and ground-ice conditions, Boulder, CO: National Snow and Ice Data Center/World Data Center for Glaciology. Digital Media. revised February 2001.

Brown, R., Derksen, C. \& Wang, L. (2007). Assessment of spring snow cover duration variability over Northern Canada from satellite dataset, Remote Sensing of Environment 111: 367-381.

Callaghan, T. V., Björn, L. O., Chernov, Y., Chapin, T., Christensen, T. R., Huntley, B., Ims, R. A., Johansson, M., Jolly, D., Jonasson, S., Matveyeva, N., Panikov, N., Oechel, W., Shaver, G., Schaphoff, S. \& Sitch, S. (2004). Effects of changes in climate on landscape and regional processes, and feedbacks to the climate system, Ambio 33(7): 459-468.

Dye, G. D. \& Tucker, C. J. (2003). Seasonality and trends of snow cover, vegetation index and temperature in northern Eurasia, Geophysical Research Letters 30(7): 1405.

Early, D. S. \& Long, D. G. (2001). Image reconstruction and enhanced resolution imaging from irregular samples, IEEE Transactions on Geoscience and Remote Sensing 39(2): 291-302.

French, H. M. (1996). The Periglacial Environment, 2nd edn, Longman, Harlow. 
Frolking, S., Fahnestock, M., Milliman, T., McDonald, K. \& Kimball, J. (2005). Interannual variability in North American grassland biomass/productivity detected by SeaWinds scatterometer backscatter, Geophysical Research Letters 32: L21409.

Frolking, S., McDonald, K. C., Kimball, J. S., Way, J. B., Zimmermann, R. \& Running, S. W. (1999). Using the space-borne NASA scatterometer (NSCAT) to determine the frozen and thawed seasons, Journal of Gephysical Research 104(D22): 27895-27907.

Hardin, P. J. \& Jackson, M. W. (2003). Investigating SeaWinds terrestrial backscatter: Equatorial savannas of South America, Photogrammetric Engineering \& Remote Sensing 69(11): 1243-1254.

Hinzman, L. D., Bettez, N. D., Bolton, W. R., Chapin, F. S., Dyurgerov, M. B., Fastie, C. L., Griffith, B., Hollister, R. D., Hope, A., Huntington, H. P., Jensen, A. M., Jia, G. J., Jorgenson, T., Kane, D. L., Klein, D. R., Kofinas, G., Lynch, A. H., Lloyd, A. H., McGuire, A. D., Nelson, F. E., Oechel, W. C., Osterkamp, T. E., Racine, C. H., Romanovsky, V. E., Stone, R. S., Stow, D. A., Sturm, M., Tweedie, C. E., Vourlitis, G. L., Walker, M. D., Walker, D. A., Webber, P. J., Welker, J. M., Winker, K. S. \& Yoshikawa, K. (2005). Evidence and implications of recent climate change in northern alaska and other arctic regions, Climatic Change 72: 251-298.

IPCC (2007). Climate Change 2007: The Physical Science Basis. Contribution of Working Group I to the Fourth Assessment Report of the Intergovernmental Panel on Climate Change, Cambridge University Press, Cambridge, United Kingdom and New York, NY, USA.

Kane, D. L. (1997). The impact of arctic hydrologic perturbations on arctic ecosystems induced by climate change, in W. C. Oechel (ed.), Global Change and Arctic Terrestrial Ecosystems, Vol. 124 of Ecological Studies, Springer, pp. 63-81.

Kane, D. L., McNamara, J. P., Yang, D., Olsson, P. Q. \& Gieck, R. E. (2003). An extreme rainfall/runoff event in Arctic Alaska, Journal of Hydrometeorology 4: 1220-1228.

Khan, V., Holko, L., Rubinstein, K. \& Breiling, M. (2008). Snow cover characteristics over the main Russian river basins as represented by reanalyses and measured data, Journal of Applied Meteorology and Climatology 47(6): 1819-1833.

Kidd, R. A., Trommler, M. \& Wagner, W. (2003). The development of a processing environment for time-series analyses of SeaWinds scatterometer data, IGARSS Proceedings, IEEE, pp. 4110-4112.

Kimball, J. S., McDonald, K. C., Frolking, S. \& Running, S. W. (2004a). Radar remote sensing of the spring thaw transition across a boreal landscape, Remote Sensing of Environment 89: $163-175$.

Kimball, J. S., McDonald, K. C., Keyser, A. R., Frolking, S. \& Running, S. W. (2001). Application of the NASA scatterometer (NSCAT) for determining the daily frozen and nonfrozen landscape of Alaska, Remote Sensing of Environment 75: 113-126.

Kimball, J. S., McDonald, K. C., Running, S. W. \& Frolking, S. E. (2004b). Satellite radar remote sensing of seasonal growing seasons for boreal and subalpine evergreen forests, Remote Sensing of Environment 90: 243-258.

Klaes, K. D., Cohen, M., Buhler, Y., Schlüssel, P., Munro, R., Luntama, J.-P., Engeln, A. V., Clerigh, E. O., Bonekamp, H., Ackermann, J. \& Schmetz, J. (2007). An introduction to the EUMETSAT polar system, Bulletin of the American Meteorological Society 88(7): 1085-1096.

Lilly, M. R., Paetzold, R. F. \& Kane, D. L. (2008). Tundra soil-water content and temperature data in support of winter tundra travel, Proceedings of the Ninth International Symposium on Permafrost, Fairbanks, Alaska, pp. 1067-71. 
Long, D. G. \& Hicks, B. R. (2005). Standard BYU QuikSCAT/SeaWinds land/ice image products, MERS Technical Report 05-04, Brigham Young University.

Mladenova, I., Lakshmi, V., Walker, J. P., Long, D. G. \& De Jeu, R. (in press). An assessment of QuikSCAT Ku-band scatterometer data for soil moisture sensitivity, IEEE Geoscience and Remote Sensing Letters .

Myneni, R. B., Keeling, C. D., Tucker, C. J., Asrar, G. \& Nemani, R. R. (1997). Increased plant growth in the northern high latitudes from 1981-1991, Nature 386: 698-702.

Naeimi, V., Bartalis, Z. \& Wagner, W. (2009). ASCAT soil moisture: An assessment of the data quality and consistency with the ERS scatterometer heritage, Journal of Hydrometeorology 10: 555-563.

Naeimi, V., Scipal, K., Bartalis, Z., Hasenauer, S. \& Wagner, W. (in press). An improved soil moisture retrieval algorithm for ERS and METOP scatterometer observations, IEEE Transactions on Geoscience and Remote Sensing .

Nghiem, S., Balk, D., Rodriguez, E., Neumann, G., Sorichetta, A., Small, C. \& Elvidge, C. (in press). Observations of urban and suburban environments with global satellite scatterometer data, ISPRS Journal of Photogrammetry and Remote Sensing .

Nghiem, S. V. \& Tsai, W.-Y. (2001). Global snow cover monitoring with spaceborne ku-band scatterometer, IEEE Transactions on Geoscience and Remote Sensing 39(10): 2118-2134.

Oza, S. R. \& Parihar, J. S. (2007). Evaluation of Ku-band QuikSCAT scatterometer data for rice crop growth stage assessment, International Journal of Remote Sensing 28(16): 34473456.

Pathe, C., Wagner, W., Sabel, D., Doubkova, M. \& Basara, J. (2009). Using ENVISAT ASAR global mode data for surface soil moisture retrieval over Oklahoma, USA, IEEE Transactions on Geoscience and Remote Sensing 47(2): 468-480.

Prigent, C., Matthews, E., Aires, F. \& Rossow, W. B. (2001). Remote sensing of global wetland dynamics with multiple satellite data sets, Geophysical Research Letters 28: 4631-4634.

Prigent, C., Papa, F., Aires, F., Rossow, W. B. \& Matthews, E. (2007). Global inundation dynamics inferred from multiple satellite observations, 1993-2000, Journal of Geophysical Research 112: D12107.

Putkonen, J. \& Roe, G. (2003). Rain-on-snow events impact soil temperatures and affect ungulate survival, Geophysical Research Letters 30(4): 1188.

Rawlins, M. A., McDonald, K. C., Frolking, S., Lammers, R. B., Fahnestock, M., Kimball, J. S. \& V\&Oumlr\&Oumlsmarty, C. J. (2005). Remote sensing of snow thaw at the pan-Arctic scale using the SeaWinds scatterometer, Journal of Hydrology 312: 294-311.

Scherer, D., Hall, D. K., Hochschild, V., König, M., Winther, J.-G., Duguay, C. R., Pivot, F., Mätzler, C., Rau, F., Seidel, K., Solberg, R. \& Walker, A. E. (2005). Remote sensing of snow cover, in C. R. Duguay \& A. Pietroniro (eds), Remote Sensing in Northern Hydrology: Measuring Environmental Change, Vol. 163 of Geophysical Monograph Series, American Geophysical Union, Washington, pp. 7-38.

Scipal, K. (2002). Global Soil Moisture Monitoring Using ERS Scatterometer Data, PhD thesis, Vienna University of Technology.

Scipal, K., Drusch, M. \& Wagner, W. (2008). Assimilation of a ERS scatterometer derived soil moisture index in the ECMWF numerical weather prediction system, Advances in Water Resources 31: 1101-1112.

Scipal, K., Scheffler, C. \& Wagner, W. (2005). Soil moisture-runoff relation at the catchment scale as observed with coarse resolution microwave remote sensing, Hydrology and Earth System Sciences 9: 173-183. 
Smith, N. V., Saatchi, S. S. \& Randerson, J. T. (2004). Trends in high northern latitude soil freeze thaw cycles from 1988 to 2002, Journal of Geophysical Research 109: D12101.

Tedesco, M. (2007). Snowmelt detection over the Greenland ice sheet from SSM/I brightness temperature daily variations, Geophysical Research Letters 34: L02504.

Ulaby, F. T., Moore, R. K. \& Fung, A. (1982). Microwave Remote Sensing-Active and Passive, Vol. II, Artech House, Norwood, Mass.

Wagner, W., Blöschl, G., Pampaloni, P., Calvet, J.-C., Bizzarri, B., Wigneron, J.-P. \& Kerr, Y. (2007). Operational readiness of microwave remote sensing of soil moisture for hydrologic applications, Nordic Hydrology 38: 1-20.

Wagner, W., Lemoine, G., Borgeaud, M. \& Rott, H. (1999c). A study of vegetation cover effects on ERS scatterometer data, IEEE Transactions on Geoscience and Remote Sensing 37(2): 938-948.

Wagner, W., Lemoine, G. \& Rott, H. (1999a). A method for estimating soil moisture from ERS scatterometer and soil data, Remote Sensing of Environment 70: 191-207.

Wagner, W., Noll, J., Borgeaud, M. \& Rott, H. (1999b). Monitoring soil moisture over the Canadian prairies with the ERS scatterometer, IEEE Transactions on Geoscience and Remote Sensing 37(1): 206-216.

Wang, L., Derksen, C. \& Brown, R. (2008). Detection of pan-Arctic terrerstrial snowmelt from QuikSCAT, 2000-2005, Remote Sensing of Environment 112(10): 3794-3805.

Way, J. B., Zimmermann, R., Rignot, E., McDonald, K. \& Oren, R. (1997). Winter and spring thaw as observed with imaging radar at BOREAS, Journal of Geophysical Research 102: 29673-29684.

Wegmüller, U. (1990). The effect of freezing and thawing on the microwave signatures of bare soil, Remote Sensing of Environment 33: 123-135.

Williams, P. J. \& Smith, M. W. (1989). The Frozen Earth: Fundamentals of Geocryology, Cambridge University Press, New York.

Wismann, V. (2000). Monitoring of seasonal thawing in Siberia with ERS scatterometer data, IEEE Transactions on Geoscience and Remote Sensing 38(4): 1804-1809.

Yang, D., Zhao, Y., Armstrong, R., Robinson, D. \& Brodzik, M.-J. (2007). Streamflow response to seasonal snow cover mass changes over large Siberian watersheds, Journal of Geophysical Research 112: F02S22.

Zhribi, M., André, C. \& Decharme, B. (2008). A method for soil moisture estimation in Western Africa based on the ERS scatterometer, IEEE Transactions on Geoscience and Remote Sensing 46(2): 438-448. 


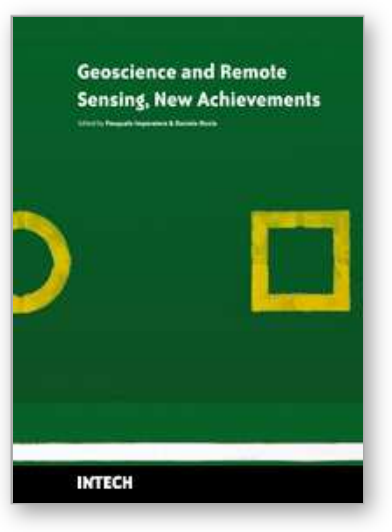

\author{
Geoscience and Remote Sensing New Achievements \\ Edited by Pasquale Imperatore and Daniele Riccio
}

ISBN 978-953-7619-97-8

Hard cover, 508 pages

Publisher InTech

Published online 01, February, 2010

Published in print edition February, 2010

Our planet is nowadays continuously monitored by powerful remote sensors operating in wide portions of the electromagnetic spectrum. Our capability of acquiring detailed information on the environment has been revolutionized by revealing its inner structure, morphology and dynamical changes. The way we now observe and study the evolution of the Earth's status has even radically influenced our perception and conception of the world we live in. The aim of this book is to bring together contributions from experts to present new research results and prospects of the future developments in the area of geosciences and remote sensing; emerging research directions are discussed. The volume consists of twenty-six chapters, encompassing both theoretical aspects and application-oriented studies. An unfolding perspective on various current trends in this extremely rich area is offered. The book chapters can be categorized along different perspectives, among others, use of active or passive sensors, employed technologies and configurations, considered scenario on the Earth, scientific research area involved in the studies.

\title{
How to reference
}

In order to correctly reference this scholarly work, feel free to copy and paste the following:

Annett Bartsch (2010). Monitoring of Terrestrial Hydrology at High Latitudes with Scatterometer Data, Geoscience and Remote Sensing New Achievements, Pasquale Imperatore and Daniele Riccio (Ed.), ISBN: 978-953-7619-97-8, InTech, Available from: http://www.intechopen.com/books/geoscience-and-remotesensing-new-achievements/monitoring-of-terrestrial-hydrology-at-high-latitudes-with-scatterometer-data

\section{INTECH}

open science | open minds

\section{InTech Europe}

University Campus STeP Ri

Slavka Krautzeka 83/A

51000 Rijeka, Croatia

Phone: +385 (51) 770447

Fax: +385 (51) 686166

www.intechopen.com

\section{InTech China}

Unit 405, Office Block, Hotel Equatorial Shanghai

No.65, Yan An Road (West), Shanghai, 200040, China

中国上海市延安西路65号上海国际贵都大饭店办公楼405单元

Phone: +86-21-62489820

Fax: $+86-21-62489821$ 
(C) 2010 The Author(s). Licensee IntechOpen. This chapter is distributed under the terms of the Creative Commons Attribution-NonCommercialShareAlike-3.0 License, which permits use, distribution and reproduction for non-commercial purposes, provided the original is properly cited and derivative works building on this content are distributed under the same license. 